\title{
The Effects of budgetary participation, budgetary slack, authority delegation, and organizational commitment on managerial performance on local government in Lam- pung, Indonesia
}

\author{
Rindu Rika Gamayuni ${ }^{1 *}$, Dewi Suryani ${ }^{2}$ \\ ${ }^{1,2}$ Accounting Department, Economic and Business Faculty, University of Lampung, Lampung, Indonesia
}

\author{
Keywords \\ Budgetary participation \\ Budgetary slack \\ Authority delegation \\ Organizational commitment \\ Managerial performance \\ Received: 7 July 2019 \\ Accepted: 8 October 2019 \\ Published: 23 December 2019
}

\begin{abstract}
This paper aims to demonstrate whether budgetary participation, budgetary slack, authority delegation, and organizational commitment positively affect the managerial performance of the local government work units. This empirical study is conducted with a local government work unit in a district/city in Lampung province, uses primary data by distributing questionnaires to 601 respondents, and is tested using SME. The study result proves that participation in budgeting preparation, budgetary slack, authority delegation, and organizational commitment will increase the managerial performance of local government work units in Lampung district. The findings imply that budgetary slack in budgeting making will affect performance, so supervision is needed on the managerial performance of local government work units so that income potential in the district of Lampung Province can be optimized.
\end{abstract}

(C) 2019 The Author(s). Published by TAF Publishing.

\section{INTRODUCTION}

To determine a budgeting, in this matter, a process is needed, Mardiasmo (2005) stated that a stage of budgeting is an important thing because ineffective budgeting and it is not oriented to performance will be able to fail the plan that has been set. Budgeting is a managerial plan of action to facilitate the achievement of organization's goal. After the process of organization goal achievement, performance evaluation is needed to be done. The performance evaluation of public sector can be obtained from financial report that can be measured based on the budgeting that has been made. Where it evaluation can be done by analyzing varians between actual performance and the one that is budgeted, where analysis of varians will focus on income varians and spending varians (regular spending varians and investment/capital spending varians) (Burki, 2017; Mardiasmo, 2002).
Young (1985) stated budgetary slack as an action estimating lower income and higher cost when agent is given an opportunity to choose work standard to improve performance. It will negatively affect public sector organization, which is when there is mistake on resource allocation and bias in performance evaluation of agent on its responsibility unit (Suartana, 2010; Wartika, Surendro, Satramihardja, \& Supriana, 2015). However, in the study from Blanchette, Pilote, and Cadieux (2002), it stated that budgetary slack conducted ethically will be able to improve performance. In Lampung Province, in 2014, determined income budgeting plan had decreased from the previous year, while determind expense budgeting plan had increased. It indicates the existence of budgetary slack in budgeting preparation, especially income budgeting.

Decentralization authority delegation is needed because in decentralized structure of managers/subordinates are given bigger authority and responsibility in decision mak-

\footnotetext{
* corresponding author: Rindu Rika Gamayuni

†email: rindu.gamayuni@yahoo.com
} 
ing. According to Miah and Mia (1996), decentralization is how far higher manager allows lower manager to take decision independently. It is supported by study of Gul, Tsui, Fong, and Kwok (1995) stating that budgetary participation on performance will positively affect organization that its authority delegation is decentralization. Different from the study of Miah and Mia (1996), Marani (2003) stating that decentralization does not positively affect managerial performance. The responsibility in delegating from top manager to lower manager will bring consequence of bigger responsibility of lower manager toward implementation of decision made. Futhermore, the study of Rachmawati (2009) and Setyarto (2008) proved that organizational commitment positively affects the performance of employees.

Based on the phenomena, theory and previous study results, then, the writer is willing to ensure more whether budgetary participation, budgetary slack, authority delegation, and organizational commitment will positively affect managerial performance of local government work unit (this empirical study is done in districts/cities in Lampung Province). For local government, the result of this study is expected to be able to give information about factors that affect managerial performance, especially in budgeting preparation at the level of local government work unit that manages Local Income.

\section{LITERATURE REVIEW}

According to Milani (1975), budgetary participation is a level of manager participation in making budgeting where budgeting used will be an instrument in defining performance. Brownell (1982) defined participatory budgeting as a level of participation and individual influence in making budgeting. Milani (1975) also argued that the level of participation and the influence of subordinate in budgeting toward decision making in budgeting process is the main factor that differentiates between participatory budgeting (Cebeci, 2016; Setyarto, 2008), so it allows subordinate to negotiate with superior in accordance with their targeted budgeting that can be obtained (Brownell \& McInnes, 1986; Dunk, 1993). According to Anthony and Govindarajan (2005) budgetary slack is the difference of budgeting amount proposed by subordinate with the best estimation amount of organization. Budgetary slack is done by subsordinate which is by presenting budgeting with low difficulty level so that it is obtained easily and this discrepancy tends to be done by subordinate because of knowing that their performance is measured by the level of budgeting attainment that has been determined together. According to Dunk
(1993) budgetary slack is defined as the express incorporation of budget amounts that make it easier to attain. Budgeting discrepancy can easily occur if information owned by subordinate/Search Results Featured snippet from the web Massively Parallel Processing (MPP) (agent) is more than information owned by superior (principal) about a responsibility center.

Authority delegation is authority giving by higher manager to lower manager to conduct a work with authorization explicitly from manager who gives authority at the time the authority is implemented (Marani, 2003). According to Bruns and Waterhouse (1975), managers in an organization with high level of decentralization feels that they are the most influencing, participate more in budgeting plan and feel satisfied by activity relating to budgeting. Contrarily, in organization with low decentralization (centralization), managers feel that they are considered less responsible, less involve in budgeting plan and having pressure from superiors.

Brownell (1982) defined organizational commitment as: the relative strength of an individual's identification with and involvement in a particular orgaization. This organizational commitment proposed by Mowday has characteristics, which are: (1) strong belief and acceptance toward goal and value of organization; (2) readiness to work hard: (3) strong willingness to stand in organization. Characteristics of organizational commitment among others are: commitment to work, commitment in group, and commitment to organization (Budiharjo, 2008; Soepomo, 1998).

Governement performance can not be measured by earnings obtained where it is possible for government to have program and activity that can produce bigger income than their cost so that government will have surplus on the program. However, this does not make government performance evaluated good, but service quality is the main goal, whether service given is adequate, so Government Financial Report will be used by groups who are interested in evaluating whether government has done distribution of expense cost fairly (Mardiasmo, 2002). Managerial performance is the level of ability, competence of a manager in implementing management activities including planning, coordinating, investigating, arranging, negotiating, representing, supervising, and evaluating. Definition of managerial performance according to Mahoney (1963), managerial performance is performance of individuals of organization members in managerial activities such as; planning, investigating, coordinating, staff arranging, negotiating, and representing. 


\section{The Effect of Participation in Budgeting Making on Man- agerial Performance}

Participation in budgeting making gives a feeling of responsibility to lower manager and encourages creativity, because on lower manager who plans or creates budgeting, the objective of budgeting is most likely the personal objective, that causes higher level of objective congruence in this matter is the high job satisfaction. The effect of participation in budgeting making toward managerial performance has been previously studied by Brownell (1982) with instrument of Milani (1975) for budgeting participation, while its managerial performance instrument uses the one from Mahoney (1963). They found that there is positive and significant relationship between participation and managerial performance as well as studies from Anthony and Govindarajan (2005), Brownell and McInnes (1986), Fernando (2013).

H1: Participation in budgeting positively affects managerial performance.

\section{The Effect of Budgetary Slack on Managerial Perfor- mance}

Budgetary slack is created by manager in order to protect self from the risk of budgeting target that can not be attained (Li, Nan, \& Mo, 2010; Milani, 1975; Suartana, 2010). When manager participates in budgeting, manager has greater responsibility to subordinate in order to be able to implement budgeting made better, as well as the existence of sanctions giving if it is less than budgeting target and compensation giving if it is able to exceed budgeting target. The existence of intervention possibility from higher management that is faced by managers if they are not able to attain budgeting target, managers will lose resources of organization, lose annual bonus or at the extreme point will lose job (Merchant, 1981). Nouri and Parker (1996) stated that if performance of a manager is evaluated based on running budgeting, then they will ensure their budgeting in the level that easily to be attained, one way is by including slack in their budgeting. According to the result of study from Dunk (1993) and Merchant (1981), budgetary slack will be low if the pressure of budgeting is low. Because manager performance is evaluated by budgeting as the only managerial performance evaluation, but according to Blanchette et al. (2002), budgetary slack done ethically will positively affect managerial performance, the study of Dunk (1995) stated that budgetary slack has positive role in affecting relationship of task difficulty and performance, in line with Davila and Wouters (2005) stating that the existence of bud- getary slack can reduce budgeting pressure and uncertainty of budgeting target attainment that affects managerial performance. Therefore, the hypothesis that is developed is:

H2: Budgetary slack positively affects managerial performance.

\section{The Effect of Authority Delegation on Managerial Per- formance}

Authority delegation is a gift that becomes rights on task and responsibility to conduct something or order others to conduct something. Marani (2003) stated that authority delegation is authority giving by higher manager to lower manager to implement an authorization explicitly from manager who gives authority at the time the authority is implemented. Therefore, subordinate or middle manager who is given authority delegation of superior or leader can help top manager in decision making, task, and responsibility with expectation that organization goal can be achieved. A manager who is given authority delegation will give effect of managerial performance, if middle management is given or not in budgeting making authority. According to the result of study from Merchant (1981), it found that budgeting system design will be effective in decentralized organization. Gul et al. (1995) in Fernando (2013) found that authority delegation positively affects managerial performance.

H3: Authority delegation positively affects managerial performance.

\section{The Effect of Organizational Commitment on Manage- rial Performance}

Organizational commitment is believed strong and supports value and target expected by organization (Brownell, 1982; Pangastuti, 2008). According to Greenberg, Baron, and Grover (1993), employee who has high organizational commitment is the employee who is more stable and more productive so eventually also more profitable for organization. Brownell (1982) stated that employee who has high organizational commitment will be more motivated to present in organization and tries to achieve organization goal (Pangastuti, 2008). Meanwhile, (Greenberg et al., 1993) stated that organizational commitment is related to high desire to share and sacrifice for organization. It is also supported by the study conducted by Fernando (2013) and Li et al. (2010) stating that organizational commitment has positive and significant effect on managerial performance of local government work unit. The formulation on hypothesis is as the following:

H4: Organizational commitment positively affects managerial performance. 


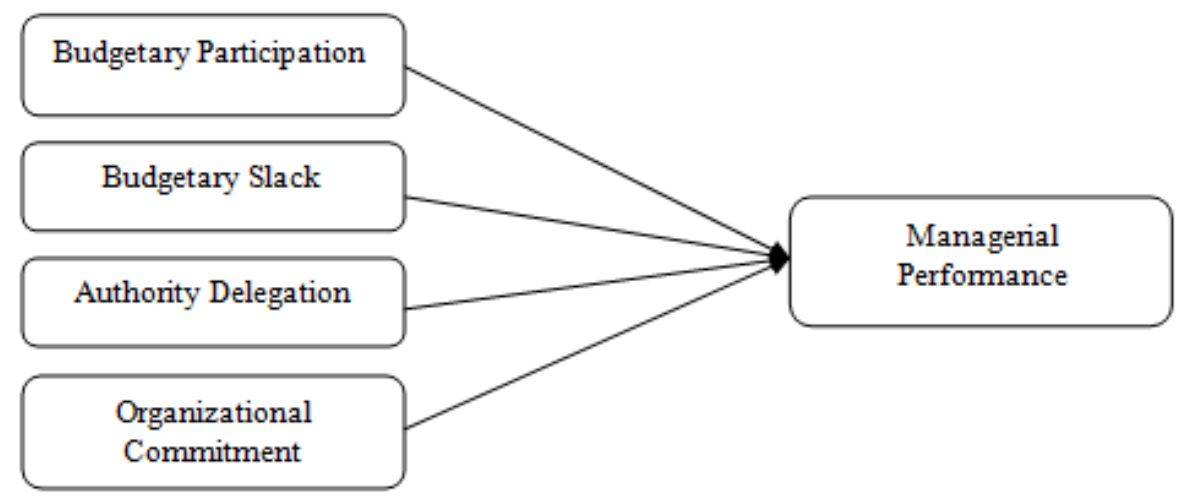

FIGURE 1. Research framework

\section{RESEARCH METHODOLOGY}

\section{Data, Population, Sample, Statistic Analysis}

This paper uses primary data by distributin questionnaires to respondent directly. Population in this study is local government work unit of Districts/Cities in Lampung Province. Sample selecting uses the method of Purposive Sampling, with criteria as the following:

1. Regions that have been established before 2007.

2. Work unit of local government that is Income Center where the responsibility center is that its manager achievement is evaluated based on the income generated.
3. Work unit of local government that has high income target. Local Real Income originated from Local Tax, Local Retribution, separated Local Resources Management and other legal Local Real Income.

Sample in this study is Income Agency, Department of Transportation, Market Department in 10 district/city governments in Lampung. 601 respondents are officials of echelon two, three, and four. Data statistic analysis uses Structural Equation Model (SEM) of Lisrel.

Variable, Dimension, and Indicator Measurement

TABLE 1. Number of nodes and edges

\begin{tabular}{|c|c|c|}
\hline Variable & Dimension & Indicator \\
\hline $\begin{array}{l}\text { Budgetary Participation } \\
\text { (Milani, 1975) }\end{array}$ & $\begin{array}{l}\text { 1. Level of involvement in bud- } \\
\text { geting planning process } 2 \text {. Effect } \\
\text { felt by Agency leader in budgeting } \\
\text { planning process }\end{array}$ & $\begin{array}{l}\text { 1.1 Participation in budgeting } \\
\text { making } 1.2 \text { Satisfaction in bud- } \\
\text { geting making } 1.3 \text { Needs to give } \\
\text { opinion } 1.4 \text { Willingness in giving } \\
\text { opinion } 2.1 \text { Magnitude of effect } \\
\text { on budgeting determination } 2.2 \\
\text { Frequency of superior in asking } \\
\text { opinion when budgeting is being } \\
\text { arranged }\end{array}$ \\
\hline $\begin{array}{l}\text { Budgetary Slack (X2) (Dunk, } \\
\text { 1993) }\end{array}$ & $\begin{array}{l}\text { 1. Budgeting standard, } 2 \text {. Budget- } \\
\text { ing achievement, } 3 \text {. Tight budget- } \\
\text { ing, } 4 \text {. Suppression budgeting, } 5 . \\
\text { Efficiency Budgeting, } 6 \text {. Budget- } \\
\text { ing target. }\end{array}$ & $\begin{array}{l}\text { 1.1 Determination of budgeting } \\
\text { standard for high productivity } 2.1 \\
\text { Easiness in target achievement } \\
\text { 3.1 Costs used must have limita- } \\
\text { tions } 4.1 \text { Few budgeting require- } \\
\text { ments } 5.1 \text { Improvement of bud- } \\
\text { geting use efficiency } 6.1 \text { Target is } \\
\text { easily attained }\end{array}$ \\
\hline $\begin{array}{l}\text { Authority Delegation (X3) (Bruns } \\
\text { \& Waterhouse, 1975) }\end{array}$ & $\begin{array}{l}\text { 1. Employee mutation, 2. Bud- } \\
\text { geting allocation, } 3 \text {. Task imple- } \\
\text { mentation specification, } 4 \text {. Oper- } \\
\text { ational decision, Decision making } \\
\text { of leaders. }\end{array}$ & $\begin{array}{l}\text { 1.1 Appointment and displace- } \\
\text { ment of employee working rela- } \\
\text { tion from leader/head of agency } \\
\text { or institution, } 2.1 \text { Playing role in } \\
\text { budgeting allocation, } 1.1 \text { Suitabil- } \\
\text { ity of the tasks mandated } 1.2 \text { Task } \\
\text { implementation that is in accor- } \\
\text { dance with determined guidance } \\
4.1 \text { Authority to make operational } \\
\text { decision Organizational Commit- } \\
\text { ment (X4) }\end{array}$ \\
\hline
\end{tabular}




\begin{tabular}{|c|c|c|}
\hline Variable & Dimension & Indicator \\
\hline (Brownell, 1982) & $\begin{array}{l}\text { 1. Strong belief and acceptance } \\
\text { toward goal and value of organi- } \\
\text { zation } 2 \text {. Readiness to work hard } \\
\text { 3. Strong desire to stand in orga- } \\
\text { nization }\end{array}$ & $\begin{array}{l}\text { 1.1 Work evaluating system that } \\
\text { is similar to organization } 1.2 \mathrm{~A} \\
\text { statement of pride working in } \\
\text { organization } 2.1 \text { Cooperation } \\
\text { readiness to achieve organization } \\
\text { goal } 1.1 \text { Organizational opportu- } \\
\text { nity to improve performance } 3.1 \\
\text { Stay in organization even though } \\
\text { changes occur in organization } \\
3.2 \text { Selection of right working } \\
\text { place that has been considered } \\
\text { previously } 3.3 \text { Great concern for } \\
\text { the future of organization }\end{array}$ \\
\hline $\begin{array}{l}\text { Managerial Performance (Y) } \\
\text { (Mahoney, 1963) }\end{array}$ & $\begin{array}{l}\text { Level of managerial Performance } \\
\text { in: } 1 \text {. Planning } 2 \text {. Investigating } 3 . \\
\text { Coordinating } 4 \text {. Evaluating } 5 . \text { Su- } \\
\text { pervising } 6 . \text { Staffing } 7 . \text { Negotiat- } \\
\text { ing } 8 \text {. Representing }\end{array}$ & $\begin{array}{l}\text { 1.1 The role of goal and activity } \\
\text { plan policy determination } 2.1 \text { Col- } \\
\text { lecting information in the form of } \\
\text { note and report } 3.1 \text { Report ad- } \\
\text { justment } 4.1 \text { Evaluation of work- } \\
\text { ing plan } 5.1 \text { Giving direction to } \\
\text { development of subordinate } 6.1 \\
\text { Placement of employee } 7.1 \text { Plays } \\
\text { role in determination of cooper- } \\
\text { ation contract } 7.2 \text { Has role in re- } \\
\text { lating with external party } 8.1 \text { Per- } \\
\text { formance evaluation and perfor- } \\
\text { mance overall target }\end{array}$ \\
\hline
\end{tabular}

\section{RESULTS}

Based on the result of validity test, all indicators have been valid except indicator K01 because it has $\mathrm{tcal}<1.96$. The result of reliability test obtained Composite Reliability value in each variable that is greater than 0.7 , then all item of questions in study variables have been reliable.

Based on the measurement of Goodness of Fit Index, it is concluded that most of parameter has fulfilled most of requirements expected which are viewed from value of GFI, AGFI, RMSEA, ECVI, AIC, NFI, NNFI and CFI that have fulfilled the requirement of goodness of fit.

The testing result on study model can be illustrated as the following:

TABLE 2. Number of nodes and edges

\begin{tabular}{lllll}
\hline \hline Relationship Model & Coefficient & Std. Error & T Cal & Information \\
\hline $\mathrm{PA} \rightarrow \mathrm{KM}$ & 0.17 & 0.044 & 3.83 & H1 is supported \\
$\mathrm{BS} \rightarrow \mathrm{KM}$ & 0.24 & 0.051 & 4.82 & H2 is supported \\
$\mathrm{PW} \rightarrow \mathrm{KM}$ & 0.22 & 0.097 & 2.31 & H3 is supported \\
$\mathrm{KO} \rightarrow \mathrm{KM}$ & 0.42 & 0.090 & 4.69 & H4 is supported \\
\hline \hline
\end{tabular}

Research equation is:

$\mathrm{KM}=0.17 * \mathrm{PA}+0.24 * \mathrm{BS}+0.22 * \mathrm{PW}+0.42 * \mathrm{KO}$

Errorvar. $=0.27, R^{2}=0.73$

Note:

PA = Budgetary Participation

$\mathrm{BS}=$ Budgetary Slack

$\mathrm{PW}=$ Authority Delegation

KO = Organizational Commitment

$\mathrm{KM}=$ Managerial Performance

The testing result of Hypothesis 1 proves that the effect of participation in budgeting making on managerial per- formance with path coefficient of 0.17 positively and significantly affects managerial performance of local government. The testing result of second hypothesis proves that Budgetary Slack positively and significantly affects managerial performance of district/city local government with path coefficient of 0.24 . The testing result of third hypothesis proves that authority delegation positively and significantly affects managerial performance of district/city local government with path coefficient of 0.22 . The testing result of fourth hypothesis proves that organizational commitment positively and significantly affects managerial performance 
of local government of district/city in Lampung, with path coefficient of 0.42 . $R^{2}$ of 0.73 means that dependent variables (budgeting participation, budgetary slack, authority delegation, and organizational commitment) can explain independent variable (managerial performance) as much as $73 \%$.

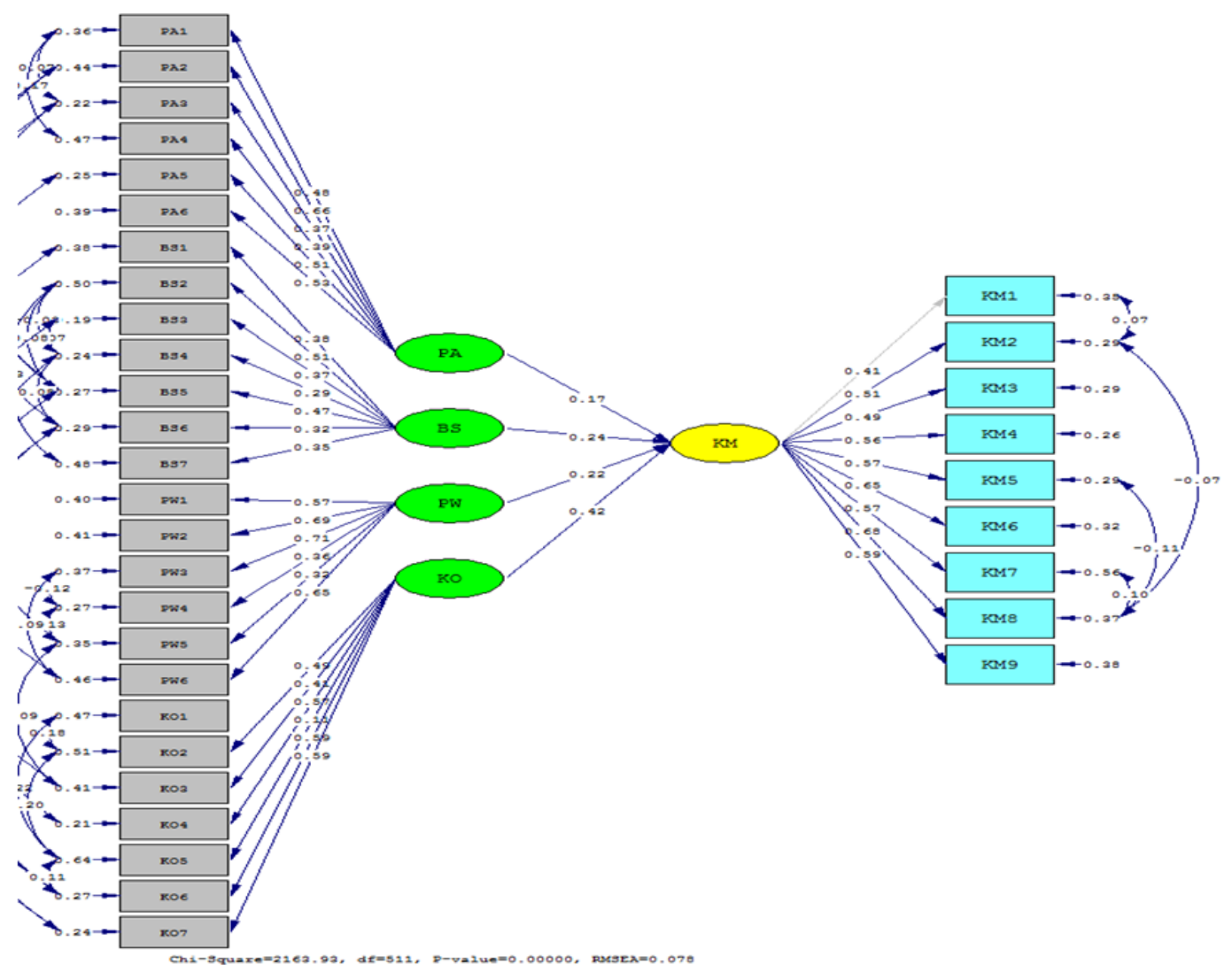

FIGURE 2. Testing result of hypothesis and SEM

\section{DISCUSSION}

The study result proves that participation in budgeting making positively and significantly affects managerial performance of distric/city government work unit in Lampung. Higher participation of in budgeting making of government work unit manager, then, managerial performance is also bigger. Participatory budgeting can be evaluated as managerial approach that can increase performance of each organization member in accordance with target that has been determined previously. Participation in budgeting making gives a feeling of responsibility to lower manager and encourages creativity, because to lower manager who plans or creates budgeting, then, budgeting objective is most likely also personal objective that causes higher level of objective congruence in this matter the high of job satisfaction. The result of this study supports the study of Bronwel and Anthony and Govindarajan (2005), Fernando (2013), Merchant (1981).

The result of this study also proves that Budgetary Slack positively and significantly affects managerial performance of district/city government work unit in Lampung, but it does not mean that government is suggested to conduct budgetary slack. In this study, budgeting is used as the base to evaluate performance of local government work unit in the following year which is by looking at budgeting realization. In this condition, it allows employees to conduct budgeting discrepancy at the time determining income target, so even though the trend of income target is always increasing, but it is still easy to be realized (budgeting absorption). Budgetary Slack is created by manager in order to be able to protect self from the risk of budgeting target that can not be attained (Li et al., 2010; Milani, 1975; Setyarto, 2008). In line with the arguments from Budiharjo (2008), Merchant (1981), Wartika et al. (2015), Young (1985) stating that the existence of budgetary slack will make manager more creative, more freely to conduct their operational activity, manager is also able to anticipate the existence of uncertainty, so morally they evaluate budgetary slack as something that is positive and ethical. Moreover, budgetary slack also can prevent manager from budgeting pressure, so performance of manager will be more stable. The existence of intervention possibility from higher manager faced 
by manager if managers are not able to attain budgeting target, then manager will lose resources of organization, lose annual bonus or at the extreme point, will lose job (Merchant, 1981). The study result is in accordance with the study of Blanchette et al. (2002) that found budgetary slack done ethically will positively affect managerial performance, as well as the study of Dunk (1995) stating that budgetary slack has positive role in affecting relationship of task difficulty and performance similarly toDavila and Wouters (2005) stating that the existence of budgetary slack can reduce budgeting pressure and uncertainty of budgeting target attainment, so it positively affects managerial performance.

Based on the result of this study, authority delegation is proven to positively affect managerial performance of district/city government work unit in Lampung. It means that the better authority delegation, the greater managerial performance. Subordinate who is given authority delegation from superior or leader can help top manager in decision making, task and responsibility with expectation that organizational objective can be achieved. The study result supports the study of Gul et al. (1995) in Fernando (2013), Marani (2003), Merchant (1981), Zulfikar (2016).

The result of this study also proves that organizational commitment positively affects managerial performance of district/city government in Lampung. The higher organizational commitment, the greater managerial performance. Strong organizational commitment inside individual will cause the individual to try hard in attaining organizational objective in accordance with organization goal and importance, as well as will have positive view and will try their best for organization importance. High commitment makes individual concern with the fate of organization and tries to make organization to be better. The study result supports the study of Fernando (2013) Greenberg et al. (1993), (Li et al., 2010), Pangastuti (2008).

\section{CONCLUSION}

1. Participation in budgeting making, budgetary slack, authority delegation, and organizational commitment positively and significantly affect managerial performance of local government of district/city in Lampung. It means that higher participation in budgeting making, budgetary slack, authority delegation, and organizational commitment, then, managerial performance will be greater.

2. Budgetary Slack has positively and significantly affects managerial performance of local government of district/city in Lampung. Where Budgetary Slack will be able to keep manager away from budgeting pressure and uncertainty of budgeting target achievement, so it affects on managerial performance improvement. This result is caused by performance evaluation of local government that is measured based on realization of budgeting target so that it needs to redefine evaluation of managerial performance. Budgetary slack is allowed as long as it is ethical. However, budgetary slack that is not ethical is not allowed.

\section{IMPLICATIONS}

For local government of Lampung Province, it should give great opportunity for its employees to participate in local budgeting makin in order to improve managerial performance in the future. Moreover, the existence of budgetary slack in budgeting making will affect performance, so supervision is needed on managerial performance of local government work unit so that income potential in District/City of Lampung Province can be optimized. Local government party also needs to develop working commitment of the employees, so they have high commitment at work. In the matter of authority delegation, for instance its responsibility that is started from planning to implementation object, it is always initiated from staff to superior that can be more optimal.

\section{REFERENCES}

Anthony, R., \& Govindarajan, V. (2005). Sistem pengendalian manajemen. Jakarta, Indonesia: Salemba Empat.

Blanchette, D., Pilote, C., \& Cadieux, J. (2002). Manager's moral evaluation of budgetary slack creation. The Accounting Review, 26, 141-162.

Brownell, P. (1982). The role of accounting data in performance evaluation, budgetary participation, and organizational effectiveness. Journal of Accounting Research, 4(7), 12-27. doi:https://doi.org/10.2307/2490760

Brownell, P., \& McInnes, M. (1986). Budgetary participation, motivation, and managerial performance. Accounting Review, 5(5), 587-600. doi:https://doi.org/10.1016/0361-3682(83)90046-6

Bruns, W. J., \& Waterhouse, J. H. (1975). Budgetary control and organization structure. Journal of Accounting Research, 177-203. doi:https://doi.org/10.2307/2490360

Budiharjo, C. (2008). Analisis pengaruh kepuasan kerja, kepemimpinan dan komitmen organisasional terhadap semangat kerja karyawan (Studi pada Balai Latihan kerja dan industri Semarang (Unpublished master's thesis). Universitas 
Diponogoro, Semarang, Indonesia.

Burki, A. K. (2017). Financial crisis and determinants of capital structure of investment banking sector in Pakistan. Journal of Administrative and Business Studies, 3(3), 153-160. doi:https://doi.org/10.20474/jabs-3.3.5

Cebeci, I. (2016). Istanbul's position as a financial center: An empirical analysis. International Journal of Business and Economic Affairs, 1(1), 1-5. doi:https://doi.org/10.24088/ijbea-2016-11001

Davila, T., \& Wouters, M. (2005). Managing budget emphasis through the explicit design of conditional budgetary slack. Accounting, Organizations and Society, 30(7-8), 587-608. doi:https://doi.org/10.1016/j.aos.2004.07.002

Dunk, A. S. (1993). The effects of job-related tension on managerial performance in participative budgetary settings. Accounting, Organizations and Society, 18(7-8), 575-585. doi:https://doi.org/10.1016/0361-3682(93)90043-6

Dunk, A. S. (1995). The joint effects of budgetary slack and task uncertainty on subunit performance. Accounting \& Finance, 35(2), 61-75. doi:https://doi.org/10.1111/j.1467-629x.1995.tb00286.x

Fernando, R. (2013). Pengaruh partisipasi penyusunan anggaran, motivasi, pelimpahan wewenang, dan komitmen organisasi terhadap kinerja manajerial skpd (Study empris di Provinsi Lampung) (Unpublished master's thesis). Universitas Diponegoro, Semarang, Indonesia.

Greenberg, J., Baron, R. A., \& Grover, R. A. (1993). Behavior in organizations: Understanding and managing the human side of work. Boston, MA: Allyn and Bacon.

Gul, F. A., Tsui, J. S., Fong, S. C., \& Kwok, H. Y. (1995). Decentralisation as a moderating factor in the budgetary participationperformance relationship: Some Hong Kong evidence. Accounting and Business Research, 25(98), 107-113. doi: https://doi.org/10.1080/00014788.1995.9729933

Li, W., Nan, X., \& Mo, Z. (2010). Effects of budgetary goal characteristics on managerial attitudes and performance. In International Conference on Management and Service Science, California, $C A$.

Mahoney, T. A. (1963). Development of managerial performance: A research approach. Ohio, OH: South-Western Publishing Company.

Marani, S. (2003). Motivasi dan pelimpahan wewenang sebagai variabel moderating dalam hubungan antara partisipasi penyusunan anggaran dengan kinerja manajerial. Journal Riset Akuntasi Indonesia, 2(5), 45-50.

Mardiasmo, M. (2002). Akuntansi sektor publik. Yogyakarta, Indonesia: Penerbit Andi.

Mardiasmo, M. (2005). Akuntansi sektor publik. Yogyakarta, Indonesia: Andi.

Merchant, K. A. (1981). The design of the corporate budgeting system: Influences on managerial behavior and performance. Accounting Review, 5(5), 813-829.

Miah, N. Z., \& Mia, L. (1996). Decentralization, accounting controls and performance of government organizations: A New Zealand empirical study. Financial Accountability \& Management, 12(3), 173-190. doi:https://doi.org/10.1111/j .1468-0408.1996.tb00186.x

Milani, K. (1975). The relationship of participation in budget-setting to industrial supervisor performance and attitudes: A field study. The accounting review, 50(2), 274-284. doi:https://doi.org/10.1016/s0361-3682(97)00036-6

Nouri, H., \& Parker, R. J. (1996). The effect of organizational commitment on the relation between budgetary participation and budgetary slack. Behavioral Research in Accounting, 8(7), 74-90.

Pangastuti, M. D. (2008). Pengaruh partisipasi penganggaran dan kejelasan sasaran anggaran terhadap kinerja manajemen pemerintah daerah dengan komitmen organisasi sebagai moderator (Studi pada Kabupaten Timor Tengah Utara) (Unpublished master's thesis). Universitas Diponegoro Semarang, Semarang, Indonesia.

Rachmawati, S. R. (2009). Pengaruh komitmen organisasi, motivasi kerja, dan gaya kepemimpinan terhadap kinerja karyawan bidang keuangan pada pemda kabupaten sukoharjo (Unpublished master's thesis). Universitas Muhammadiyah Surakarta, Surakarta, Indonesia.

Setyarto, A. (2008). Pengaruh gaya kepemimpinan, profesionalisme, komitmen organisasi, dan kepuasan kerja terhadap kinerja karyawan bagian akuntansi (Survey pada koperasi simpan pinjam di wilayah kota madya surakarta) (Unpublished master's thesis). Universitas Muhammadiyah Surakarta, Surakarta, Indonesia.

Soepomo, B. (1998). Pengaruh struktur dan budaya organisasi terhadap efektifitas partisipasi penyusunan anggaran dalam peningkatan kinerja manajerial studi empiris pada perusahaan manufaktur di Indonesia (Unpublished master's thesis). Universitas Diponegoro, Semarang, Indonesia.

Suartana, I. W. (2010). Akuntansi keperilakuan teori dan implementasi. Yogyakarta, Indonesia: Andi. 
Wartika, K., Surendro, H., Satramihardja, I., \& Supriana. (2015). Business process improvement conceptual models to improve the efficiency of power consumption on computer use from the perspective of human resource performance. International Journal of Business and Administrative Studies, 1(3), 99-106. doi:https://doi.org/10.20469/ijbas.10004-3

Young, S. M. (1985). Participative budgeting: The effects of risk aversion and asymmetric information on budgetary slack. Journal of Accounting Research, 23(2), 829-842. doi:https://doi.org/10.2307/2490840

Zulfikar, S. (2016). Pengaruh pelimpahan wewenang, partisipasi anggaran, komitmen organisasi, dan motivasi kerja terhadap kinerja manajerial SKPD kabupaten karanganyar (Unpublished master's thesis). Universitas Muhammadiyah Surakarta, Surakarta, Indonesia. 